\title{
Distributed Green Technologies for Regenerating Greyfields
}

\section{Introduction}

The chapter begins by looking at the history of technological change and how big shifts occur after major economic crisis. It will then outline the transition to new technologies and urban systems after the COVID-19based economic crisis to show why and how distributed green technologies are likely to be mainstreamed in the 2020s and beyond. This will need to be associated with tangible urban system planning changes such as the regeneration of greyfield precincts to form part of a wider urban technological transition. Indeed, it should be possible to use the greyfieldgreening process as a substantial catalyst in creating twenty-first-century net zero urban developments linked with the best in smart, innovative, affordable urban technology.

Mainstreaming such technology requires initiating socio-technical transitions that enable distributed infrastructure to flourish (Newton, 2008; Newton et al., 2019). This chapter provides some ideas on how this transition will occur for each type of green distributed infrastructure with application to both types of greyfield regeneration: the place-based systems will be less dense and so can do more with green infrastructure; 
the transit-based systems will be denser with more opportunity for shared distributed technologies. Innovative case studies from Perth will be used to illustrate this rapid change in technology based on demonstrations of distributed renewable energy and storage; integrated water systems; and zero waste to landfill using closed-loop circular economies. Each of the case studies involves smart technology systems for sharing and efficiency.

\subsection{Technological Innovation: The Sixth Wave}

The 2020 collapse of the global economy due to the COVID-19 pandemic has challenged planners to think about long-term trends and what the future could hold for cities and regions, especially in the context of the climate agenda. The history of economic transitions after crises reveals that they unleash waves of new technologically based innovation (Batty, 2018). Historically, these have been associated with different energy and infrastructure systems and their impact on transport and urban forms. Typically, the new technologies had already begun to emerge before the start of each economic collapse, then proceeded to induce a new economy to emerge as new investors chose to create something better and longer-lasting. This is happening now in cities across the world, and certainly in Australia (Newman, 2020).

Figure 3.1 and Table 3.1 set out the establishment of each of the six waves of innovation and the emergence of the new sixth wave, which involves a critical convergence between the digital transformation ushered in by the fifth wave and the green technologies driving the sixth wave. The new smart sustainable green economy is likely to be driven for the next 30 years and beyond by global sustainability agendas, such as the 2015 Paris Agreement and the work of the United Nations Sustainable Development Group, and have a strong base in a cluster of innovative technologies: renewable energy, electro-mobility, integrated watersensitive biophilic urbanism (the basis of blue-green cities), circulareconomy technologies, and smart cities, which can all be seen as representing distributed green technologies. The resulting urban transformations from these new infrastructure systems are likely to build relocalised centres and denser precincts (Newman, 2020; Mathews, 2018), 


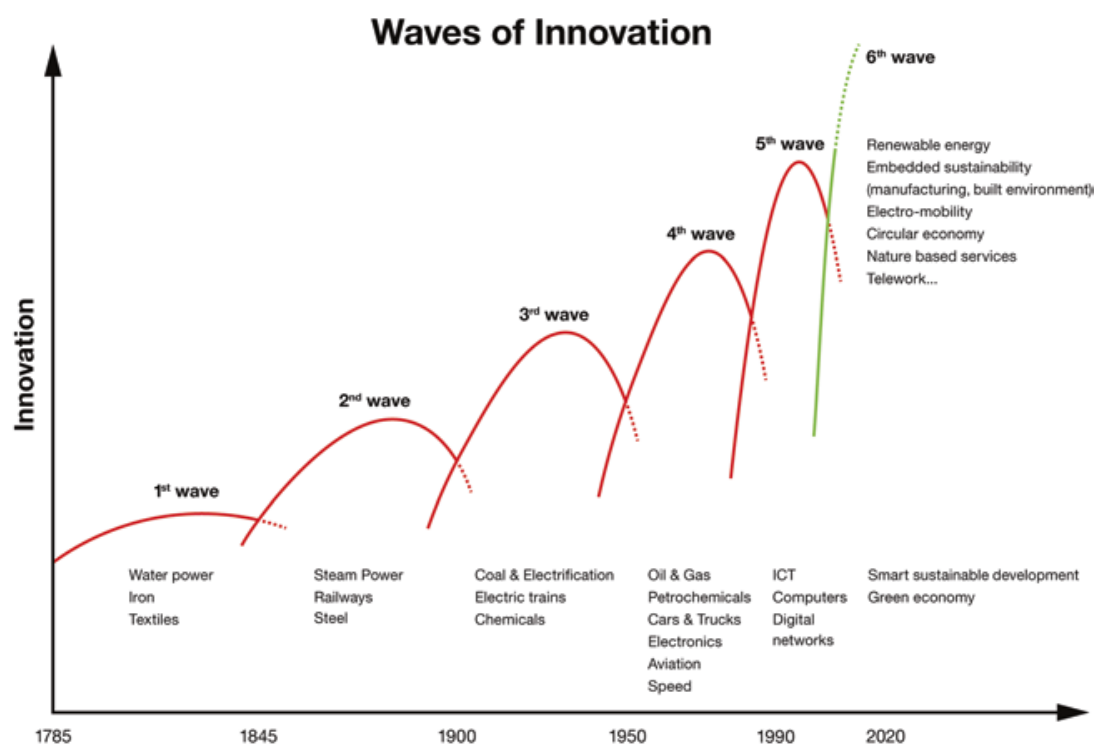

Fig. 3.1 Waves of innovation through industrial history and into the future. (Source: Adapted from Hargroves \& Smith, 2005)

core elements in greening the greyfields. This book will set out how best to enable these technologies within the context of greyfield regeneration.

The innovations for this sixth wave are able to attract the cultural and political momentum attached to something much wanted and needed (Rifkin, 2019), but which has not been possible until now (Webb et al., 2018). The opportunity for rapid growth in the new green economy rests on a surplus of savings in the world and a cost of capital expected to be low for many years. Consequently, substantial long-term loans can drive the next green economy, including an agenda of greening the greyfields, particularly when greyfields projects are presented as the net-zero demonstrations that the world of finance is now requiring them to be (Garnaut, $2019,2021)$. As shown below, they are also likely to be the cheapest way to do urban redevelopment. 
Table 3.1 Technological, societal, and settlement transitions

\begin{tabular}{|c|c|c|c|c|}
\hline $\begin{array}{l}\text { Economic } \\
\text { waves }\end{array}$ & $\begin{array}{l}\text { Technological } \\
\text { innovations } \\
\text { emerging }\end{array}$ & Business model & $\begin{array}{l}\text { Energy and } \\
\text { infrastructure }\end{array}$ & $\begin{array}{l}\text { Transport and } \\
\text { city form }\end{array}$ \\
\hline $\begin{array}{l}\text { 1. } 1780 \text { s to } \\
1840 \text { s } \\
\text { Industrial } \\
\text { Revolution }\end{array}$ & $\begin{array}{l}\text { Water power, } \\
\text { iron, } \\
\text { mechanisation, } \\
\text { textiles, } \\
\text { commerce }\end{array}$ & $\begin{array}{l}\text { Small and } \\
\text { cottage } \\
\text { industries }\end{array}$ & $\begin{array}{l}\text { Water power } \\
\text { and } \\
\text { horsepower, } \\
\text { canals and } \\
\text { sailing-ship } \\
\text { ports; roads for } \\
\text { carriages } \\
\text { linking cities }\end{array}$ & $\begin{array}{l}\text { Walking cities } \\
\text { rapidly } \\
\text { densifying } \\
\text { from industry }\end{array}$ \\
\hline $\begin{array}{l}\text { 2. } 1840 \text { s 'Hard } \\
\text { Times' } \\
\text { followed by } \\
\text { Victorian } \\
\text { prosperity }\end{array}$ & $\begin{array}{l}\text { Steam power, } \\
\text { railroads, } \\
\text { steel, } \\
\text { cotton }\end{array}$ & $\begin{array}{l}\text { Cottage } \\
\text { industries into } \\
\text { large capital } \\
\text { firms and } \\
\text { factories }\end{array}$ & $\begin{array}{l}\text { Wood and steam } \\
\text { into train } \\
\text { systems }\end{array}$ & $\begin{array}{l}\text { Walking cities } \\
\text { into rail- } \\
\text { based linear } \\
\text { urban } \\
\text { development }\end{array}$ \\
\hline $\begin{array}{l}\text { 3. 1890s Great } \\
\text { Depression } \\
\text { followed by } \\
\text { Belle } \\
\text { Epoque }\end{array}$ & $\begin{array}{l}\text { Electricity, } \\
\text { chemicals, } \\
\text { internal } \\
\text { combustion } \\
\text { engine }\end{array}$ & $\begin{array}{l}\text { Monopolistic } \\
\text { Fordist } \\
\text { Firms and } \\
\text { factories }\end{array}$ & $\begin{array}{l}\text { Coal and electric } \\
\text { tram and rain } \\
\text { systems }\end{array}$ & $\begin{array}{l}\text { Tram and } \\
\text { train-based } \\
\text { corridors }\end{array}$ \\
\hline $\begin{array}{l}\text { 4. 1930s Great } \\
\text { Crash } \\
\text { followed by } \\
\text { Keynesian } \\
\text { growth }\end{array}$ & $\begin{array}{l}\text { Petrochemicals, } \\
\text { aviation, } \\
\text { electronics, } \\
\text { space }\end{array}$ & $\begin{array}{l}\text { Multinationals, } \\
\text { modernism }\end{array}$ & Oil and freeways & $\begin{array}{l}\text { Automobile- } \\
\text { based urban } \\
\text { sprawl }\end{array}$ \\
\hline $\begin{array}{l}\text { 5. 1980s } \\
\text { Dot-Com } \\
\text { recession } \\
\text { followed by } \\
\text { knowledge } \\
\text { economy }\end{array}$ & $\begin{array}{l}\text { Digital } \\
\text { networks, } \\
\text { biotechnology, } \\
\text { information } \\
\text { technology }\end{array}$ & $\begin{array}{l}\text { Flexible } \\
\text { specialisation } \\
\text { and } \\
\text { networked } \\
\text { globalism }\end{array}$ & $\begin{array}{l}\text { Communications } \\
\text { superhighway } \\
\text { and ICT systems }\end{array}$ & $\begin{array}{l}\text { Revival of } \\
\text { urban centres } \\
\text { around } \\
\text { knowledge } \\
\text { economy }\end{array}$ \\
\hline $\begin{array}{l}\text { 6. } 2020 \text { s } \\
\text { COVID } \\
\text { Collapse } \\
\text { followed by } \\
\text { green } \\
\text { economy }\end{array}$ & $\begin{array}{l}\text { Renewable } \\
\text { energy, } \\
\text { circular } \\
\text { economy, } \\
\text { smart city }\end{array}$ & $\begin{array}{l}\text { Global } \\
\text { localisation }\end{array}$ & $\begin{array}{l}\text { Renewables with } \\
\text { batteries, } \\
\text { electro-mobility, } \\
\text { especially } \\
\text { non-car-based, } \\
\text { smart cities, } \\
\text { hydrogen for } \\
\text { industry, } \\
\text { circular } \\
\text { economy, } \\
\text { biophilic } \\
\text { urbanism }\end{array}$ & $\begin{array}{l}\text { Re-localised } \\
\text { centres, } \\
\text { smart, } \\
\text { distributed } \\
\text { infrastruc- } \\
\text { ture, } \\
\text { transit- } \\
\text { activated } \\
\text { corridors fed } \\
\text { by micro- } \\
\text { mobility, and } \\
\text { active } \\
\text { transport }\end{array}$ \\
\hline
\end{tabular}




\section{New Distributed Technologies}

\subsection{Renewable Energy, Rooftop Solar, and Batteries}

The dramatic global growth in renewable energy (solar and wind) in the past decade (Fig. 3.2) has been due to these technologies quickly becoming the cheapest form of power as well as being easy to mass-produce and

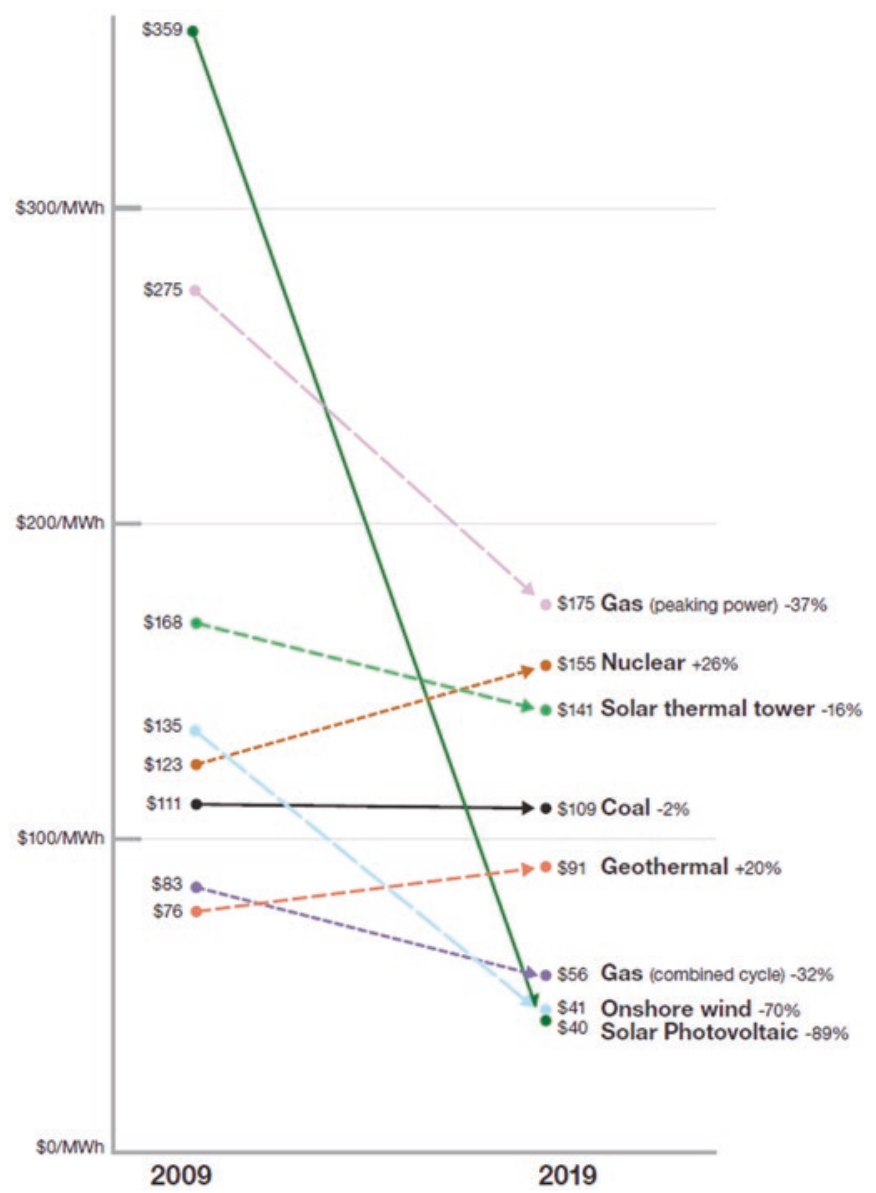

Fig. 3.2 Dramatic changes in world's power sources in the past decade. (Source: Drafted from data provided in OurWorldinData.org) 
implement in most cities and economies. This is particularly so with rooftop solar power, as it enables local production and consumption to be integrated, providing the base for localising other infrastructures.

The new patterns of urbanism that are emerging around these systems are already showing why cities will become much more distributed into local areas of infrastructure management-but they will still need to be integrated into a city-wide or region-wide grid system for equity and balance (Green \& Newman, 2017; Newton \& Newman, 2013). Distributed technologies lend themselves to precinct-scale development because of the benefits that result from clustered utility networks between multiple buildings (such as load balancing, economies of scale, and affordable sharing of the new technologies). The rapid growth in solar power has now moved into shared solar systems for medium- and high-density housing enabled by localised solar utilities with batteries and blockchainbased management; industrial estates with shared solar power appear to be next, although rural and remote settlements were among the first expected to benefit from solar technology (Galloway \& Newman, 2014).

The next task appears to be how to achieve grid stabilisation, and this seems to be heading toward localised, community-scale batteries (Sproul, 2019). These are becoming available for many other urban functions including electro-mobility, which, as shown in Chap. 4, can be part of grid stabilisation. Gas turbines (and diesel back-up in small grids) have been seen as necessary for grid stabilisation, but lithium-ion batteries are now cost-effective at over $150 \mathrm{MW}$, making them cheaper than gas turbines and more effective at providing a rapid peaking function (Denholm et al., 2019). This means that precincts of zero-carbon development will have an important role in future grid management, especially as electricvehicle batteries can become part of this integrated low-carbon grid system in a cheaper way than the large-scale fossil fuel energy systems of the twentieth-century economy.

Thus, $100 \%$ renewable power grids can now be built cost-effectively (AEMO, 2020) and should be part of every new or retrofitted precinct. This is now a market-driven process but is helped by the large and growing sector of ethical investing and the commitment to only funding Net Zero projects by the world's largest finance company Blackrock and the other 574 investment companies representing US\$54 trillion in Climate 
100+ (https://www.climateaction100.org/) (Fink, 2020). However, there is still work to be done on how to make shared solar power work in precincts (DISER \& ARUP, 2020; Green et al., 2020). Greyfield regeneration at precinct scale represents an important target for demonstrating how to integrate a range of distributed green technologies.

\subsection{Integrated Water-Sensitive Systems Combined with Biophilic Urbanism}

Stormwater capture and wastewater treatment can also be harnessed to minimise demand on centralised potable-water systems to support distributed green infrastructure (nature-based systems that fulfil urban functions and facilitate adaptation to climate change, as discussed in Chap. 5). There is a growing ability to do this at precinct scale that has been mainstreamed in many places (Byrne et al., 2020; Kenway et al., 2019; Newton \& Rogers, 2020). Harvesting rainwater at building and precinct scale is now increasingly on the urban-planning agenda in an age of drying climates for many cities.

The use of small-scale wastewater treatment systems has been trialled in places like Hammarby-Sjostad in Sweden (Newman et al., 2017) but this is not likely to be easy for most cities. However, the most obvious need is to build water-sensitive cities that use grey water for local purposes (Byrne et al., 2020). This is part of an integrated water system that includes rainwater harvesting and stormwater capture. These new urban water-management techniques enable biophilic urbanism and blue-green cities as a means of better linking water to local open space and gardens, as well as building natural systems into and onto buildings with green roofs and green walls and converting engineered concrete drains to natural water courses. The best examples have been in dense tropical cities like Singapore that have been able to use high-rise structures as greened habitat (Newman, 2014), but there is no reason why greyfield precincts could not feature such a mix of blue-green technologies and nature-based services (Newton \& Rogers, 2020). The biophilic-cities and nature-based systems networks are growing worldwide (Dumitru \& Wendling, 2021) and are demonstrating that local biophilic features of cities are playing a 
very strong role during the COVID-19 lockdown in providing a healthy link to nature (https://www.biophiliccities.org/covid19-research). The GPR model employs biophilic urbanism concepts for both water-sensitive and biodiversity-sensitive design in 'missing middle' medium-density residential redevelopment (Chap. 7).

\subsection{Circular-Economy Technologies}

Cities have been attempting for some time to reduce their metabolism (i.e., their resource inputs and waste outputs; see Newman \& Kenworthy, 1999). This has been given a new boost as the core agenda for a circular economy (GI-REC, 2018; Petit-Boix \& Leipold, 2018). The technology for waste disposal traditionally has been centralised, large-scale, and largely linear rather than circular; that is, it has been landfill-based and had little emphasis on recycling unless cities were running out of space. The new systems for the circular economy are, like the other innovations discussed above, much smaller in scale and can be used in more localised and distributed situations. A circular economy can include zero waste in precinct construction (USGBC, 2019); how food waste can be managed locally in compost systems at precinct scale (Graham et al., 2019); and how micro-factories located within municipalities can accept a range of local waste streams such as plastics and transform them into useful products (Sahajwalla, 2019; Perinotto, 2021). Larger new industrial estates operating on industrial-ecology principals and capable of processing multiple waste flows at larger volumes are also essential parts of a new green urban economy, but their locations are likely to be in peri-urban regions.

\subsection{Smart City-Based Demand Management}

Smart Cities, an agenda that has rapidly grown in the twenty-first century, has many features aligned with regenerative urban development. The cluster of innovations relevant to distributed green infrastructuresolar photovoltaic power, batteries, electro-mobility, circular economy, and integrated water and waste systems-have two key characteristics: they are modular and thus can be employed in urban precinct design as 
localised systems; and they work even better if resource consumption and waste generation is reduced. Both can be influenced significantly by smart city-based demand management as long as they are part of strategic urban planning.

Localised systems. New smart-city technologies include an ability to enable any system to learn and self-optimise through artificial intelligence (AI) and machine learning. Many functions of AI have been envisioned to help the zero-carbon agenda (Rolnick et al., 2019), but optimising precinct infrastructure through machine learning is just emerging. GPR operations can be optimised with the application of sensors to manage their energy, water, waste, and mobility more effectively by continuously learning from resident occupants as their data are being processed, and by providing feedback, often in real time. They are akin to neural networks that are constantly improving the urban ecosystem in which they operate.

Welfare for people with disabilities or those in aged care can also be improved with these kinds of infrastructure systems; for example, through service monitoring and management, resource optimisation, and identifying areas for cost-efficiency. Localised smart systems can be managed to provide more-effective solutions for the operation of the built environment, and greyfield precincts are an ideal scale for medium-density, mixed-use development where shared infrastructure and services can become the norm.

Reduced consumption. Smart technologies can be used to reduce consumption by supporting change in household behaviour and social practices and subsequent demand and supply management (Creutzig et al., 2018). Smart building demand management systems (Pears \& Moore, 2019) enable householders and businesses to understand what they are consuming at any point in time with mobile phone apps and appliance displays in homes and offices, and simple programmable options that build in the optimal efficiencies for use of energy, water, and other services (Byrne et al., 2019). These include apps, such as the Climate Clever Homes calculator, that identify the best utility-services options for a local area (https://www.climateclever.org/homes); they can also be built in from the start as part of a zero-carbon home or precinct. A renewed focus on re-localising living, working and activity spaces associated with COVID-19 has the prospect of advancing the growth of 20-minute neighbourhoods and reducing travel and emissions. 


\section{$3 \quad$ Case Studies}

\subsection{White Gum Valley}

In the suburb of White Gum Valley (WGV) in Perth, Australia, a new GPR project has been developed using many of the technologies outlined above to demonstrate how it could meet zero-carbon and other United Nations Sustainable Development Goals (SDGs) (Wiktorowicz et al., 2018) using One Planet Living accreditation. The project has 100 units of housing on an old school site and has been redeveloped in close consultation with the local community at medium-density levels of approximately 45 dwellings per hectare. Development of WGV has been facilitated by having only one owner (the land-development agency DevelopmentWA).

WGV features a range of building types, including two-, three-, and four-storey apartment clusters and attached and detached homes. They all rely on leading energy strategies including:

- Climate-responsive design and landscaping, including strategic use of trees for seasonal shading

- A minimum seven-star Nationwide House Energy Rating Scheme (NatHERS) energy efficiency rating for its houses

- Rooftop solar power of $3.5 \mathrm{~kW}$ (minimum) for all houses

- Strata-owned solar panels and batteries on apartments using peer-topeer energy sharing

- Shared electric vehicle for use by the community

- Energy-efficient hot-water systems, heating, cooling, appliances, and lighting

Other features include:

- Rainwater harvesting for household use

- Stormwater reuse through a community bore to irrigate private and public gardens 
- Community green space created from an old stormwater sump, demonstrating water-sensitive and biophilic design

- Apartment living designed to suit students and an artist-run housing cooperative

Applied research undertaken by Curtin University, with the CRC for Low Carbon Living (https://developmentwa.com.au/projects/residential/white-gum-valley/overview) addressed multiple sustainability issues, including energy and water use, technology performance, the interrelation between behaviour change, design, and technology, the facilitation of knowledge sharing (Thomson et al., 2019; Byrne et al., 2019; Breadsell et al., 2019a, b). To test the viability of solar battery storage on strata buildings, the project demonstrated the potential for a blockchain-based sharing system, and potential for a new 'citizen utility' governance model, gaining attention from around the world (Green \& Newman, 2017; Green et al., 2020; Eon et al., 2019).

The significance of innovation at WGV is that it demonstrated that a net-zero carbon urban regeneration project can:

- Be commercially viable

- Contribute to the Paris Agreement target that seeks to achieve deep decarbonisation while also delivering the United Nations SDGs

- Build an integrated development using new green distributed technology and support a first international demonstration of how to share solar energy through blockchain

- Ensure community trust and support by meeting other sustainability goals via the One Planet Living international accreditation process.

\subsection{East Village}

East Village is a planned, 1000-person residential development similar to neighbouring WGV that incorporates a blockchain system built in from the outset for sharing energy, water, and solar-power systems (Byrne et al., 2020). The first stage includes 36 townhouses and two 
adjoining apartment sites for 60 dwellings, to be occupied at a higher density than WGV (https://developmentwa.com.au/projects/residential/east-village-at-knutsford/overview). The project's strata systems allow the townhouses and apartments (which are individually owned) to share infrastructure as well as the more conventional access to common property, and are managed by the strata management company. Individual dwellings are metered, with smart meters and blockchain technology providing each home the potential to both produce and consume energy and water that may be shared between properties, and to enable recharging of electric vehicles using a shared fast charger. This smart metering allows for resource optimisation and reduces utility costs. The integration of infrastructure through smart technology enables creation of net-zero, affordable, regenerative development of greyfields. The project also contains a circular-economy demonstration building made entirely of recycled products (https://www. architectureanddesign.com.au/news/curtin-university-living-labshowcases-sustainable).

\section{Conclusion}

The regeneration of greyfield precincts represents an opportunity to trial new technologies in combination with precinct-scale urban regenerative planning and design. COVID-19 is a potential accelerator of these innovative, distributed green infrastructure systems, given the widespread debate that has begun about 'what needs to change' in cities. Innovations that were ripe for implementation pre-COVID now have a new opportunity to be mainstreamed. Perhaps the world's cities are poised to create a new model of precinct-driven urban regeneration based on:

- Distributed renewable energy with battery storage as well as smart ICT technologies that create distributed energy markets

- Electro-mobility and associated new transit capacity, walkability, and micro-mobility (Chap. 4) 
- Localised integrated water management and biophilic urbanism that bring natural systems into built environments to achieve new urban habitats and blue-green infrastructure

- Circular-economy systems applied to waste streams that are applicable at both local community and precinct scale

- Smart-city technologies that enable these urban innovations to work better, and together to create more intelligent and effective city ecosystems that learn and evolve, demonstrating how to make each place in a city or region achieve multiple sustainable development goals and outcomes

Urban professionals will need to rapidly change the manuals of modernism still so prevalent in their fourth-wave engineering designs and statutory regulations, or else they will miss these early chances to be part of the sixth wave. This book is designed to help cities quickly focus on how to mainstream their new planning and assessment systems to create new sustainability exemplars of zero-carbon, affordable urbanism in innovative greyfield regeneration programmes.

\section{References}

AEMO. (2020). Renewable integration study. Australian Energy Market Operator. https://aemo.com.au/-/media/files/major-publications/ris/2020/ renewable-integration-study-stage-1.pdf?la=en

Batty, M. (2018). Inventing future cities. MIT Press.

Breadsell, J., Byrne, J., \& Morrison, G. (2019a). Pre- and post-occupancy evaluation of resident motivations for and experiences of establishing a home in a low-carbon development. Sustainability, 11(14), 1-17.

Breadsell, J., Eon, C., Morrison, G., \& Kashima, Y. (2019b). Interlocking practices and their influence in the home. Environment and Planning B: Urban Analytics and City Science, 46(8), 1405-1421.

Byrne, J., Berry, S., \& Eon, C. (2019). Transitioning to net zero homes Learnings from the CRC's high-performance housing living laborato- 
ries. In P. Newton, D. Prasad, A. Sproul, \& S. White (Eds.), Decarbonising the built environment: Charting the transition (pp. 143-162). Palgrave Macmillan.

Byrne, J., Mouritz, M., Taylor, M., \& Breadsell, J. (2020). East village at Knutsford: A case study in sustainable urbanism. Sustainability, 12, 6296. https://doi.org/10.3390/su12166296

Creutzig, F., Roy, J., Lamb, W. F., Azevedo, I. M. L., de Bruin, W. B., Dalkmann, H., Edelenbosch, O. Y., Geels, F. W., Grubler, A., Hepburn, C., Hertwich, E. G., Khosla, R., Mattauch, L., Minx, J. C., Ramakrishnan, A., Rao, N. D., Steinberger, J. K., Tavoni, M., Ürge-Vorsatz, D., \& Weber, E. U. (2018). Towards demand-side solutions for mitigating climate change. Nature Climate Change, 8, 260-263. https://doi.org/10.1038/ s41558-018-0121-1

Denholm, P., Nunemaker, J., Gagnon, P., \& Cole, W. (2019). The potential for battery energy storage to provide peaking capacity in the United States. National Renewable Energy Laboratory. NREL/TP-6A20-74184. https://www.nrel. gov/docs/fy19osti/74184.pdf

DISER. \& ARUP. (2020). Precincts to support the delivery of zero energy (and carbon) ready building. Australian Government.

Dumitru, A., \& Wendling, L. (2021). Evaluating the impact of nature-based solutions: A handbook for practitioners. European Commission.

Eon, C., Breadsell, J., Morrison, G., \& Byrne, J. (2019). Shifting home energy consumption through a holistic understanding of the home system of practice. In P. Newton, D. Prasad, A. Sproul, \& S. White (Eds.), Decarbonising the built environment: Charting the transition (pp. 431-448). Palgrave Macmillan.

Fink, L. (2020). A fundamental reshaping of finance. Blackrock. https://www. blackrock.com/au/individual/larry-fink-ceo-letter

Galloway, D., \& Newman, P. (2014). How to design a sustainable heavy industrial estate. Renewable Energy, 67, 46-52.

Garnaut, R. (2019). Superpower: Australia's low-carbon opportunity. Latrobe University Press.

Garnaut, R. (2021). Reset: Restoring Australia after the pandemic recession. Latrobe University Press.

GI-REC. (2018). Circular economy indicators: What do they measure? Global Initiative for Resource Efficient Cities. https://resourceefficientcities. org/2018/11/circular-economy-indicators-what-do-they-measure/ 
Graham, P., Waller, V., \& Christie, B. (2019). Towards low-carbon urban metabolism-The impact of eliminating food waste. In P. Newton, D. Prasad, A. Sproul, \& S. White (Eds.), Decarbonising the built environment: Charting the transition (pp. 321-336). Palgrave Macmillan.

Green, J., \& Newman, P. (2017). Citizen utilities: The emerging power paradigm. Energy Policy, 105, 283-293. http://www.sciencedirect.com/science/ article/pii/S0301421517300800

Green, J., Newman, P., \& Forse, N. (2020). RENew Nexus: Enabling localised electricity markets through P2P and VPP trading. Power Ledger and Curtin University.

Hargroves, K., \& Smith, M. (2005). The natural advantage of nations: Business opportunities, innovation and governance in the 21st century. The Natural Edge Project, Earthscan.

Kenway, S. J., Lam, K. L.,, Beata, S. \& Renouf, M. A. (2019). Integrated urban water systems. In P. Newton, D. Prasad, A. Sproul, \& S. White (Eds.), Decarbonising the built environment (pp. 287-304). Palgrave Macmillan.

Mathews, J. (2018). Schumpeter in the 21st century: Creative destruction and the global green shift. In R. Kattel \& L. Burlamqui (Eds.), Schumpeter's Capitalism, Socialism and Democracy, A 21st Century Agenda (pp. 233-254). Routledge.

Newman, P. (2014). Biophilic urbanism: A case study of Singapore. Australian Planner, 51, 47-65.

Newman, P. (2020). Covid, cities and climate: Historical and potential transitions for the new economy. Urban Science, 4(3), 32. https://www.mdpi. com/2413-8851/4/3/32\#abstract

Newman, P., \& Kenworthy, J. (1999). Sustainability and cities. Island Press.

Newman, P., Beatley, T., \& Boyer, H. (2017). Resilient cities: Overcoming fossil fuel dependence. Island Press.

Newton, P. (2008). Transitions: Pathways towards sustainable urban development in Australia. Springer.

Newton, P., \& Newman, P. (2013). The geography of solar PV and a new low carbon urban transition theory. Sustainability, 5(6), 2537-2556.

Newton, P., \& Rogers, B. (2020). Transforming built environments: Towards carbon neutral and blue-green cities. Sustainability, 12, 4745. https://doi. org/10.3390/su12114745

Newton, P., Prasad, D., Sproul, A., \& White, S. (Eds.). (2019). Decarbonising the built environment: Charting the transition. Palgrave Macmillan. 
Pears, A., \& Moore, T. (2019). Decarbonising household energy use: The smart meter revolution and beyond. In P. Newton, D. Prasad, A. Sproul, \& S. White (Eds.), Decarbonising the built environment: Charting the transition (pp. 99-115). Palgrave Macmillan.

Perinotto. (2021, April 19). The Fifth Estate (2021). Building Circularity. https:// issuu.com/thefifthestateebook/docs/building_circularity_ebook_2021

Petit-Boix, A., \& Leipold, S. (2018). Circular economy in cities: Reviewing how environmental research aligns with local practices. Journal of Cleaner Production, 195, 1270-1281.

Rifkin, J. (2019). The Green New Deal. St Martins Press.

Rolnick, D., Donti, P.L., Kaack, L.H., Kochanski, K., Lacoste, A., Sankaran, K., Ross, A.S., Milojevic-Dupont, N., Jacques, N., Waldman-Brown, A., Luccioni, A., Maharaj, T., Sherwin, E.D., Mukkavilli, S.K., Kording, K.P., Gomes, C., Ng, A.Y., Hassabis, D., Platt, J.C., ... Bengio, Y. (2019, June 19). Tackling climate change with machine learning. arXiv. https://arxiv.org/ pdf/1906.05433.pdf

Sahajwalla, V. (2019, October 10). Microfactory turns recycling on its head: Transforming recyclables into useful plastic products. Cosmos. https://cosmosmagazine.com/incredible-modular-microfactory-turns-plastic-recyclingon-its-head/

Sproul, A. (2019). Rooftop photovoltaics: Distributed renewable energy and storage (or low-cost PV changes everything). In P. Newton, D. Prasad, A. Sproul, \& S. White (Eds.), Decarbonising the built environment: Charting the transition (pp. 53-64). Palgrave Macmillan.

Thomson, G., Newton, P., Newman, P., \& Byrne, J. (2019). Guide to low carbon precincts. Cooperative Research Centre for Low Carbon Living.

USGBC. (2019). Zero waste in construction. https://www.usgbc.org/education/sessions/greenbuild-2019/zero-waste-construction-12707592

Webb, R., Bai, X., Smith, M. S., Costanza, R., Griggs, D., Moglia, M., Neuman, M., Newman, P., Newton, P., Norman, B., Ryan, C., Schandl, H., Steffen, W., Tapper, N., \& Thomson, G. (2018). Sustainable urban systems: Co-design and framing for transformation. Ambio, 47, 57-77. https://doi. org/10.1007/s13280-017-0934-

Wiktorowicz, J., Babaeff, T., Breadsell, J., Byrne, J., Eggleston, J., \& Newman, P. (2018). WGV: An Australian urban precinct case study to demonstrate the $1.5{ }^{\circ} \mathrm{C}$ Agenda including multiple SDGs. Urban Planning, 3(2), 64-81. https://doi.org/10.17645/up.v3i2.1245 
Open Access This chapter is licensed under the terms of the Creative Commons Attribution 4.0 International License (http://creativecommons.org/licenses/ by/4.0/), which permits use, sharing, adaptation, distribution and reproduction in any medium or format, as long as you give appropriate credit to the original author(s) and the source, provide a link to the Creative Commons licence and indicate if changes were made.

The images or other third party material in this chapter are included in the chapter's Creative Commons licence, unless indicated otherwise in a credit line to the material. If material is not included in the chapter's Creative Commons licence and your intended use is not permitted by statutory regulation or exceeds the permitted use, you will need to obtain permission directly from the copyright holder.

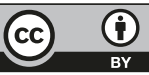

